\title{
21018 音響浮遊液滴の界面変形と内部流動の相関に関する研究 \\ Study on correlation between interfacial deformation and internal flow in an acoustically levitated droplet
}

\author{
○学 池田 啓 （筑波大院）＼cjkstart正＼cjkstart金子＼cjkstart曉子（筑波大）＼cjkstart学 山本 祐司（筑波大院） \\ 学 長谷川 浩司（筑波大院） 正 阿部 豊（筑波大）＼cjkstart学 河上 雅則（筑波大院）
}

Hiromu IKEDA, Yutaka ABE and Akiko KANEKO,

University of Tsukuba, 1-1-1, Tennoudai, Tsukuba, Ibaraki, 305-8573, Japan

\begin{abstract}
Under the microgravity environment, products of new and high quality materials solidified into homogeneous crystal have been the subject of much interest. Usually, a large levitated droplet is utilized for such a containerless processing. However, surface instability and internal flow appear remarkably when the droplet becomes large. Elucidation of effect of surface instability and internal flow of the levitated droplet is required for the quality improvement of new material. In the previous study, internal flow is confirmed on levitated droplet. In the present study, the experimental investigation of levitated droplet by ultrasound is conducted under the normal gravity environment. The purpose of this study is examined the effects on internal flow when the equivalent diameter and aspect ratio of levitated droplet. In this experiment we focus on the flow transition and the flow condition. The internal flow structure in the levitated droplets is measured by two dimensional Particle Image Velocimetry (PIV) techniques, and the dominant factor which induces the internal flow is discussed.
\end{abstract}

Key Words : Droplet, Acoustic levitation, Internal Flow, PIV, Deformation

\section{1. 緒 言}

現在，宇宙開発技術の向上によりスペースシャトルや国 際宇宙ステーション(ISS)などの微小重力環境を用いた研究 が行われつつある. 微小重力環境においては材料生成プロ セスにおいて地上とは異なり容器を必要としないことによ り高品質な材料が得られることが期待されている。また，流 体内の温度差や異種材料間の密度差に起因する浮力が働か ず，対流や沈殿が生じないため地上より静的な環境で材料 の製造が可能という利点がある.しかしながら，静的な環境 である宇宙においても浮遊物体に僅かに力がかかるため液 体物体を限られた空間に留める保持力を必要とする。その 際，浮遊する液体内部の流動が顕著になる可能性がある。こ のような内部流動は新材料製造の均質性などに影響を及ぼ すことが指摘されており，新材料製造において内部流動メ カニズムの解明が求められている。これまでに液滴の浮遊 や水液滴の内部流動観測など様々な研究 ${ }^{(1)-(4)}$ が行われてき た。過去の研究において, 浮遊液滴内部には流動が発生する ことが確認され, 物性值の影響も受けることが調べられてい る.しかしながら, 内部流動発生要因, 液滴内部の流動状況 など, 具体的な液滴内部流動に関する奏験的研究は未だ十分 であるとは言い難い。

本研究では，浮遊液滴の液滴径および扁平率の変化によ る内部流動への影響を調べることを目的とする．実験にお いては, 内部流動の遷移,またそのときの流動状況に着目し, 液滴内部の赤道面に発生寸る二次元的な流動, また流動発生 要因を調べることとした。具体的には試験流体に水を用い て, 液滴径および音圧を変化させたとき, 内部流動を可視観 測する.また, 得られた内部流動観測画像に対し, PIV 解析 を施すことによって液滴内部の流動構造を把握し, 扁平摔お よび液滴径の内部流動への影響を調べる.

\section{2. 実験装置および実験方法}

図 1 に本研究で使用した実験装置の概略図を示す，液滴を 浮遊させるには, 関数発信機から正弦信号を発信し, アンプ を介して増幅した後, 電力計を通して超音波振動子八入力 する.これにより超音波振動子を駆動し，振動子に接続され
た固体スピーカーであるホーンを介して，ホーンと反射板 であるガラス板の間に音響定在波を形成する。この音響定 在波によって液滴はホーン間に保持される。

また，ホーンーガラス板間の音圧はプローブマイクロフ オンを用いて計測する。浮遊液滴の内部流動は液滴内部に トレーサ粒子を添加しレーザーシートによって反射した粒 子像を上方ハイスピードカメラから撮影することによって 観測する。浮遊液滴の外形は水平方向からのハイスピード ビデオカメラを用いて観測する.

実験条件としてはホーン間距離 $46 \mathrm{~mm}$, 入力周波数 19.4 $\mathrm{kHz}$, 音压 161-163 dB, 液滴径 2-5 mm, 扁平率 1.2-2.4, 室 温 $20{ }^{\circ} \mathrm{C}$ で実験を行い，試験流体は水を用いた．水の物性を Table.1に示す.また, ハイスピードカメラの撮影条件は 1000 FPS とした。

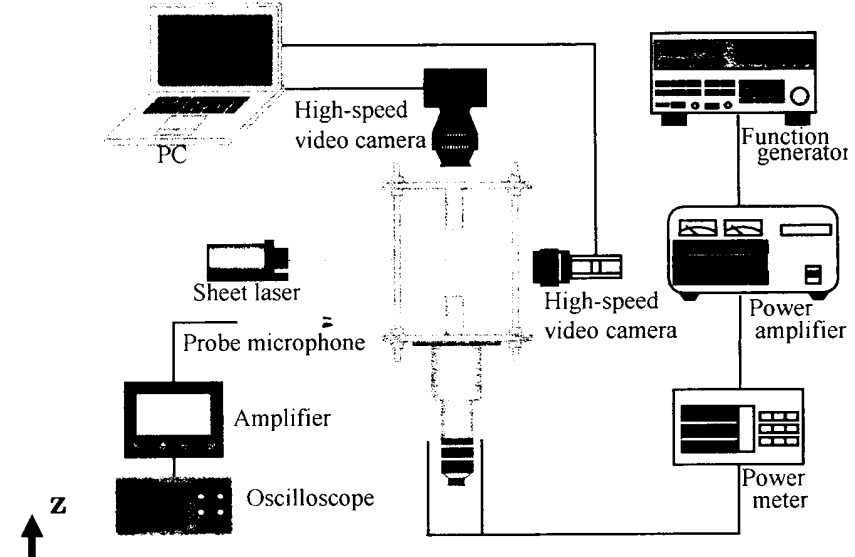

Fig.1 Experimental apparatus Table1 Physical properties of test fluids

\begin{tabular}{cccc}
\hline Fluid & $\begin{array}{c}\text { Viscosity } \\
{[\mathrm{m} \mathrm{Pa} \cdot \mathrm{s}]}\end{array}$ & $\begin{array}{c}\text { Surface tension } \\
{[\mathrm{m} \mathrm{N} / \mathrm{m}]}\end{array}$ & $\begin{array}{c}\text { Density } \\
{\left[\mathrm{kg} / \mathrm{m}^{3}\right]}\end{array}$ \\
\hline water & 0.890 & 72.8 & 998 \\
\hline
\end{tabular}




\section{3. 実験結果および考察}

図 2 (a) に水平方向から撮影された実際の水液滴の外形を 示す．液滴は音響放射圧力と重力の影響により，扁平形にな っていることが確認できる. 扁平率は液滴の横軸および縦 軸をそれぞれ $a, b$ とし以下の式(1)で示す。

$$
\text { Aspect ratio }=\frac{a}{b} \quad \cdots(1)
$$

また図 2 (b) は液滴内部のトレーサ粒子像である. 液滴の 赤道面にレーザーシートを照射し，その赤道面をガラスプ レートを用いた可視化空を通して上方向から観測した，浮 遊液体赤道面に照射されたシートレーザーにより，トレーサ 粒子が反射しているのが確認できる。これらの観測画像を もとに 1000 枚の画像を PIV 処理し, 平均した水の内部流動 の様子を図 3 に示す. 図 3 より水液滴の赤道面は, 赤道面中 央に流れが生じ, また内部に右回りと左回り両方の流れをも つ流れが発生していることが観測された。扁平率および液 滴径の変化によって図 3 のような流動場を液滴内部に持つ 流動が観測されたことからこのの双対渦を内部に持つ特徵的 な流れに着目した。

液滴内部の速度場は赤道面中央付近に最大流速が発生し ている.この流動が発生した場合の扁平率と液滴等価直径 で整理したものを図 4 に示す. 図 3 のような双対渦が確認 された条件を黒抜きの三角プロットに示す. 双対渦は扁平 率が約 1.6-2.0, 液滴等価直径が $3 \mathrm{~mm}$ 以上のときに生じて いることが確認できる. 双対渦が確認できなかった流動は 白抜きの四角プロットで示している. 双対渦以外の流れは, 低アスペクト比のとき剛体的な回転挙動, 高アスペクト比に なると双対渦とは異なる非定常な流動構造が観測された.ま た図 4 中の斜線部分は, 液滴が音圧増加によって起こる界面 振動や微粒化，また音響放射圧力と液滴の自重の釣り合い が保てずに液滴が落下するような安定浮遊しない領域を示 す. 図4から扁平率および夜滴径が大きくなるにつれて流動 状況が遷移し, 一定の範囲において図 3 のような流動場を内 部にもつ流れが確認された.このことから内部流動は界面 変形および液滴径によって変化することが示唆された。

これらの実験結果より, 音響浮遊液滴内部の流動は液滴径, 扁平率の影響を受けることが考えられる. 液滴の形状が比 較的球形状に近く, 液滴径が小さい場合, 液滴は剛体的な回 転をすることが確認された. 扁平率, 液滴径が大きくなるに つれて今回着目した図 3 のような特徽的な流れが一定の範 囲で発生し, さらに扁平率が増加した場合, 液滴の内部流動 は遷移し, 非定常な流動構造をもつことが確認された。この 遷移の要因として, 液滴径の増加による音響定在波の節から の低下, 扁平率の増加によって音響放射圧力を受ける面積が 增えることが内部流動への影響の一つとして考えられる。 音響定在波中の節からの低下によって, テスト部定在波中の 腹に近づくため, 定在波の変動を強く受けることによって内 部に流動が発生することが考えられる。これらの要因によ り浮遊液滴の内部流動が液滴径および扁平率の増加に伴っ て遷移していくことが示唆される。
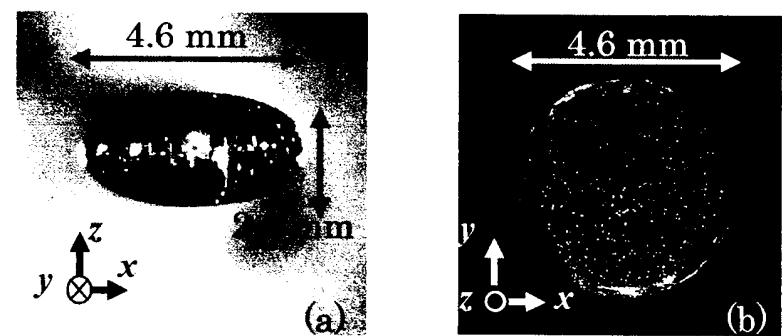

Fig.2 (a) Horizontal view of droplet, (b) Equatorial plane view of levitated droplet

(Aspect ratio $=2.1, d=3.6[\mathrm{~mm}], S P L=162[\mathrm{~dB}])$

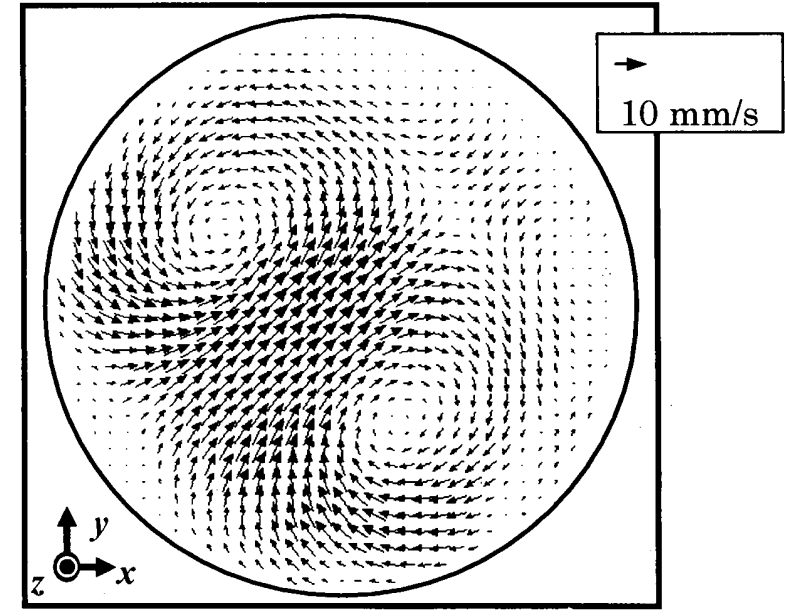

Fig.3 Two-dimensional velocity vector distr.bution in the equatorial plane of the water droplet

(Aspect ratio $=2.1, d=3.6[\mathrm{~mm}], S P L=162[\mathrm{~dB}]$ )

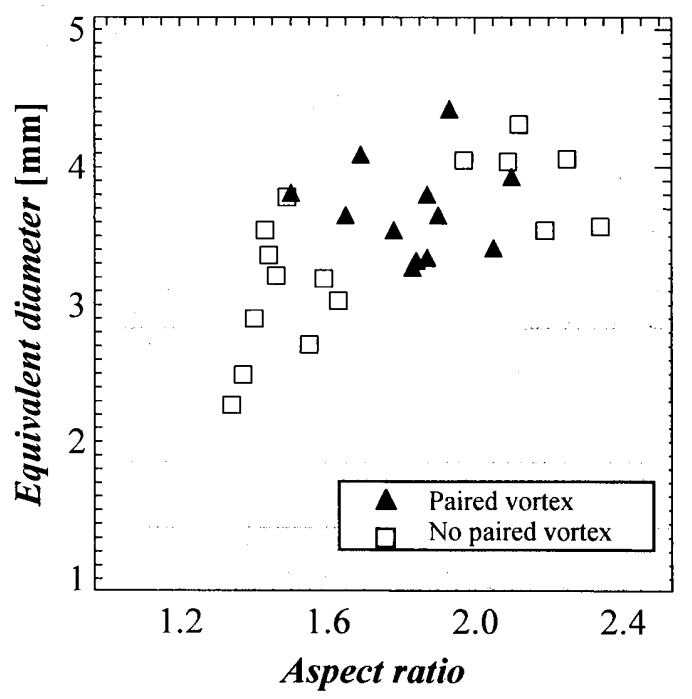

Fig.4 Correlation between the aspect ratio and equivalent diameter

4. 結 言

・液滴径および扁平率を変化させたとき浮遊液滴の内部には 異なる流動が発生することを確認した。

・扁平率, 液滴径が一定の範囲のとき浮遊液滴赤道面上左右 に異なる渦度をもつ双対渦の流れが観測された。

・液滴径, 界面変形が大きくなるにつれて, 浮遊液滴内部の 流動が顕著になることが示唆された。

- 今後は浮遊夜滴赤道面の三成分速度を算出し, $z$ 軸方向の 流れを考慮し，流動場を把握する予定である。

\section{参 考 文. 献}

(1) A. V. Anilkumar, C. P. Lee, and T. G. Wang, Phys. Fluid A, Vol. 5, No. 11, pp. 2763-2774 (1993).

(2) E. Trinh, A. Zwern and T. G. Wang, J. Fluid Mech. Vol. 115, pp. 453-474 (1982).

(3) Y Abe, D Hyuga, S Yamada, K Aoki, Ann. N.Y. Acad. Sci.1077, pp. 49-62 (2006)

(4) Y Abe, A Kaneko, Y Yamamoto, K Hasegawa, K Aoki, Microgravity Sci. Technol, 20, pp. 277-280 (2008) 